\title{
Online Travel Service Quality: The Role of Pre- Transaction Services
}

Citation for published version (APA):

van Riel, A. C. R., Semeijn, J., \& Pauwels, P. F. J. (2004). Online Travel Service Quality: The Role of PreTransaction Services. Total Quality Management, 15(4), 475-493.

https://doi.org/10.1080/1478336042000183578

Document status and date:

Published: 01/01/2004

DOI:

10.1080/1478336042000183578

Document Version:

Publisher's PDF, also known as Version of record

\section{Please check the document version of this publication:}

- A submitted manuscript is the version of the article upon submission and before peer-review. There can be important differences between the submitted version and the official published version of record.

People interested in the research are advised to contact the author for the final version of the publication, or visit the DOI to the publisher's website.

- The final author version and the galley proof are versions of the publication after peer review.

- The final published version features the final layout of the paper including the volume, issue and page numbers.

Link to publication

\footnotetext{
General rights rights.

- You may freely distribute the URL identifying the publication in the public portal. please follow below link for the End User Agreement:

www.umlib.nl/taverne-license

Take down policy

If you believe that this document breaches copyright please contact us at:

repository@maastrichtuniversity.nl

providing details and we will investigate your claim.
}

Copyright and moral rights for the publications made accessible in the public portal are retained by the authors and/or other copyright owners and it is a condition of accessing publications that users recognise and abide by the legal requirements associated with these

- Users may download and print one copy of any publication from the public portal for the purpose of private study or research.

- You may not further distribute the material or use it for any profit-making activity or commercial gain

If the publication is distributed under the terms of Article $25 \mathrm{fa}$ of the Dutch Copyright Act, indicated by the "Taverne" license above, 


\title{
Online Travel Service Quality: the Role of Pre-Transaction Services
}

\author{
ALLARD C. R. VAN RIEL*, JANJAAP SEMEIJN** \& \\ PIETER PAUWELS* \\ *Department of Marketing, Faculty of Economics and Business Administration, Maastricht \\ University, Maastricht, the Netherlands, **Department of Management Sciences, Open \\ University Netherlands, Heerlen, the Netherlands
}

\begin{abstract}
The Internet revolution has led to significant changes in the way travel agencies interact with customers. Travel websites are used to different degrees, and for a variety of combinations of pre-transaction, transaction and post-transaction services. A better understanding of how customers interact with online services will help providers improve service quality to levels that satisfy or even delight customers, and thus create loyalty. This article provides a comprehensive review of the literature on online service quality, applies the theory to online travel offerings, and reports on an empirical study of quality perceptions of pre-transaction services provided on three travel websites. Effects on customer responses were measured for process and outcome dimensions of online service quality. Implications for the design of online travel services and suggestions for further research are formulated.
\end{abstract}

KeY WoRDS: Online service quality, internet travel agencies, pre-transaction services

\section{Introduction}

Travel agencies provide a broad range of services, largely consisting of information exchange and information processing activities. Information intended to support customers in their travel decision-making is generally provided in pretransaction services. In addition, in transaction services the customer's personal information and payments are collected, verified and processed, and information is relayed to third party transportation and hospitality providers. Finally, in post-transaction services travel agents communicate last-minute information to the customer and provide after-sales assistance. As the travel industry is largely information-driven, the World Wide Web is considered ideally suited as a medium for these activities (Adamic \& Huberman, 2000; Morgan et al., 2001; Peterson et al., 1997), and it is hardly surprising that online travel services have developed into one of the largest e-commerce domains (Anckar \& Walden, 2000; Clemons et al., 2002). There is great diversity among travel agencies' use of IT and the Web. Most traditional travel agencies have at least a basic presence on the Internet to promote their business or to exchange e-mail with customers. More

Correspondence Address: A. C. R. van Riel, Maastricht University, Department of Marketing, PO Box 616, NL 6200 MD Maastricht, the Netherlands. Email: a.vanriel@mw.unimaas.nl 
sophisticated travel sites allow customers to search, select or arrange travel and holiday packages, and to make reservations and bookings themselves. In spite of the slowdown occurring in other e-commerce areas, the online travel business has shown sustained growth (TravelWeekly, 2001).

The Internet has increased competition among travel agents considerably. Even if price plays only a secondary role in online services (Pan et al., 2002; Reichheld \& Schefter, 2000; Smith, 2002), the information efficiency of the Internet still poses a substantial threat, as all online travel agencies offer similar services. Service quality may help create differentiation between providers, thereby further easing price competition (Clemons et al., 2002), and may therefore be among the most important success factors of any Internet business (Zeithaml et al., 2002). Excellent online service will satisfy or even delight customers and increase their patronage (Rust \& Oliver, 2000), resulting in desirable behaviours such as word-of-mouth promotion, willingness to pay a price premium and repurchasing (Reichheld et al., 2000; Reichheld \& Schefter, 2000; Reichheld \& Teal, 1996). Nonetheless, only a few sites are reported to appeal to their customers, and even fewer create significant value to the customer and the provider (Grönroos et al., 2000).

The issue of quality management has become quintessential in the travel and tourism industry, which is suffering from a general slowdown since 11 September 2001, the wars in Afghanistan and Iraq, and the outbreak of the SARS virus in Asia. Despite the increased importance of quality, satisfaction and loyalty in the travel industry (Augustyn, 1998; Augustyn \& Ho, 1998), and the increasingly important role of the Internet in the service encounter, surprisingly few research articles have been dedicated to the issue of online (self-) service quality in the travel domain. Research in the field of customer evaluations of self-service technology (Dabholkar, 1996; Meuter et al., 2000) and online services is generally considered to be in an early stage. Developing general insight in the determinants of perceived e-service quality, and the influence of e-service quality perceptions on satisfaction and loyalty is of great academic interest, but insufficient to help service managers make adequate decisions, since the dimensionality of service quality is dependent on the type of services offered (Babakus \& Boller, 1992). Therefore, what is currently needed is research focusing on specific service categories. For travel agencies desiring to survive and thrive on the Internet, and willing to invest in online services, it is critical to know precisely how customers will evaluate their full service offer and which service categories and quality dimensions are valued most (Jeong \& Lambert, 2001; Jeong et al., 2003). Hence, the problem statement of the present study reads:

Which factors play a role in customer evaluations of online travel service quality?

Three sub-questions were formulated.

(1) How do customers perceive and use online travel services?

(2) To what extent can traditional measures be used for online service quality?

(3) Which quality dimensions do customers of online travel services consider important?

The study aims to explore the issue of customer quality perceptions of travel websites. First, differences in the way consumers perceive and use traditional and 
online services will be identified, and the consequences of these differences for the conceptualization of online travel service quality will be discussed. A model of online travel service quality will be developed, which will be validated in an empirical study. In the conclusion, implications and directions for future research are presented.

\section{Review of the Literature and Development of Propositions}

Loyal customers are important to companies because they contribute directly and sustainably to the profitability and viability of the firm. Online customers express their loyalty to a service provider in various ways (Reichheld, 1994; Reichheld et al., 2000; Reichheld \& Teal, 1996; Viitanen et al., 2004; Zeithaml et al., 1996). Their commitment to the firm is reflected in return- and re-purchase behaviour, the willingness to pay a price premium, and favourable word-ofmouth. In an online setting, word-of-mouth can spread quickly. Online customers can easily use e-mail, often offered by the provider in the form of a web-link, to recommend their favourite web site to friends and family.

Positive and reciprocal relationships are often assumed to exist between customer loyalty, service quality, and customer satisfaction in offline and online contexts (Bowen \& Clarke, 2002; Shankar et al., 2003), although the precise nature of these relationships, and the validity of offline loyalty theories in an online environment are still under debate (Jeong et al., 2003). Indeed, loyal customers are typically satisfied customers, but satisfaction does not universally translate into loyalty (Oliver, 1999). Service quality and customer satisfaction have been used interchangeably as antecedents of loyalty, but a feeling of consensus is growing that they are fundamentally different in terms of antecedents and outcomes (Zeithaml \& Bitner, 2000). Causal links are thought to exist between service quality, satisfaction and loyalty, while nature, direction and strength of the links depend on the type of service (Dabholkar, 1996) and the position of the encounter in the customer-provider relationship lifecycle. Transaction and post-transaction service quality is considered crucial to overall loyalty (Reibstein, 2002) while, especially in the case of online travel services, satisfaction with pre-transaction services will be important, as it may lead to return behaviour and favourable word-of-mouth. Positive service quality perceptions are assumed to lead to increased satisfaction, 'the perception of pleasurable fulfillment' (Oliver, 1999: p. 34) and value attributions (Zeithaml \& Bitner, 2000). On the other hand, Dabholkar (1996) found that satisfaction with the use of technology has a substantial effect on service quality evaluations. It appears very difficult, if not impossible, to influence satisfaction, loyalty or patronizing behaviour of online customers directly. However, online service quality can be assessed, managed and controlled. In the following we will therefore focus on online service quality.

\section{A Conceptualization of Online Travel Services}

In analogy with other services, online travel services can be viewed as a composite offer, consisting of core services and peripheral or auxiliary services (Grönroos, 
1994; Grönroos et al., 2000). In a traditional service context, the reason for the provider to be in the market is generally seen as the core service (e.g. selling travel packages for a traditional travel agent), while the auxiliary services are considered to exist in order to facilitate the use of the core service or to enhance the value of the offer. The situation is considerably different in an online context. Whereas it may be obvious to customers of traditional providers what their core services are, this is not the case in an online environment. What customers perceive as the core service of an online service offer will depend on their momentary needs and preferences regarding Internet usage. To leisure customers, who may prefer making actual transactions in the travel agency, pre-transaction services could comprise the core service of a travel website, while transaction services may constitute the core service for business customers. Building on Grönroos' (1994) theory, and mindful of the idea of 'customerization' (Wind \& Rangaswamy, 2001), we propose an adapted - genuinely customer-based conceptualization of online services: the online core service will be the customer's reason for using the website, whether this core service be making the transaction, or making use of pre- or post-transaction services.

This adaptation has consequences for the conceptualization of online auxiliary services. Auxiliary services have been subdivided into facilitating and supporting services. Facilitating services are considered essential for making the service accessible (Grönroos et al., 2000). In the case of an online travel agency, facilitating services would, for example, consist of search engines, reservation systems and secure paying methods. Although facilitating services are essentialand thus common to all competing service offers - they can still be designed in a distinctive fashion, adding value for the customer (Grönroos et al., 2000).

Supporting services have been considered non-essential, added to the website mainly to differentiate the service package (Grönroos et al., 2000). For online travel agencies, supporting services could for example be currency calculators, weather forecasts, information about health issues, general country information, chat-rooms, traveller storybooks, or links to other websites. As explained in the above, it is conceivable that customers view certain supporting services as the core service or as an indiscernible part of the core service. This is the case when a customer uses a travel agent's website uniquely for checking the local weather forecast, typically a pre- or post transaction service. In an online context, the role of supporting services must therefore be reconsidered: while they may not seem essential to the provider, supporting services are often crucial to the customer, and therefore potentially very important in distinguishing the service offer from those of competitors, provided they are tailored to the needs of the customer.

\section{Modelling and Measuring Service Quality}

Parasuraman et al. $(1985,1988)$ were among the first to introduce a formal service quality model. The model was based on the disconfirmation paradigm, introduced to consumer behaviour research by Oliver (1977). A combination of theoretical and empirical research resulted in the 22-item SERVQUAL scale (Parasuraman et al., 1985, 1988), which has become widely accepted and used: The quality of traditional services is now generally measured along five 
fundamental quality dimensions: tangibles (the appearance of physical facilities, equipment, personnel, and communication materials), reliability (the ability of the firm to perform the promised service dependably and accurately), responsiveness (willingness to help customers and provide prompt service), assurance (knowledge and courtesy of employees and their ability to convey trust and confidence), and empathy (the caring and individualized attention provided to the customer).

The dimensionality of the SERVQUAL model has often been questioned (Brown et al., 2002; Caruana, 2000). The five-component factor structure is indeed confirmed in few if any of the research samples (Caruana, 2000; Cronin $\&$ Taylor, 1992). This lack of confirmation has been explained by suggesting that the dimensionality is strongly dependent on the type of service being offered (Babakus \& Boller, 1992). How well the SERVQUAL model can be used for online services is also under debate. Several authors have proposed to use traditional service quality theory as a basis for further empirical research regarding online services (Grönroos et al., 2000; Kaynama \& Black, 2000; Zeithaml et al., 2000). Zeithaml et al. (2000) for example developed 11 SERVQUAL-related dimensions, based on focus group research. According to Liljander et al. (2002) the original dimensions can be adapted to online services, and some additional dimensions should be constructed. With the objective of adapting and extending traditional service quality dimensions, viewing online services as a Self Service Technology (SST), which enables customers to service themselves without the involvement of employees, can be very helpful (Dabholkar, 1996, 2000; Dabholkar \& Bagozzi, 2002; Meuter \& Bitner, 1998; Meuter et al., 2000, 2001).

Viewing online services as a SST has consequences for the conceptualization of the online service encounter. The service encounter can be considered to lie on the basis of the traditional SERVQUAL model. In a traditional service setting, customers are often thought to base their quality judgements mainly on evaluations of physical aspects of the service provider on the one hand (Bitner, 1992), and their interactions with service employees on the other (Bitner, 1990; Bitner et al., 1990). In much service quality research, the so-called service encounter (Solomon et al., 1985) is identified with the service itself (Groth et al., 2001). In particular, the quality and perceived value of human interaction between customer and service staff during the encounter (Bolton \& Drew, 1992) are considered critical in determining future patronage behaviour. In many online service encounters, however, customers interact exclusively with technology and will only deal with employees when special help is needed. Furthermore, a visit to the provider's premises is generally unnecessary, or secondary. The traditional service encounter is thus replaced by an interaction with technology and it can be expected that online service quality perceptions will be based largely on evaluations of this interaction. Therefore, a key determinant of online service quality appears to be the user interface, which represents the service provider (Grönroos et al., 2000).

\section{The User Interface}

Technology can enable and facilitate the exchange of information between customers and the service provider (Parasuraman \& Grewal, 2000). In the case 
Online service offer

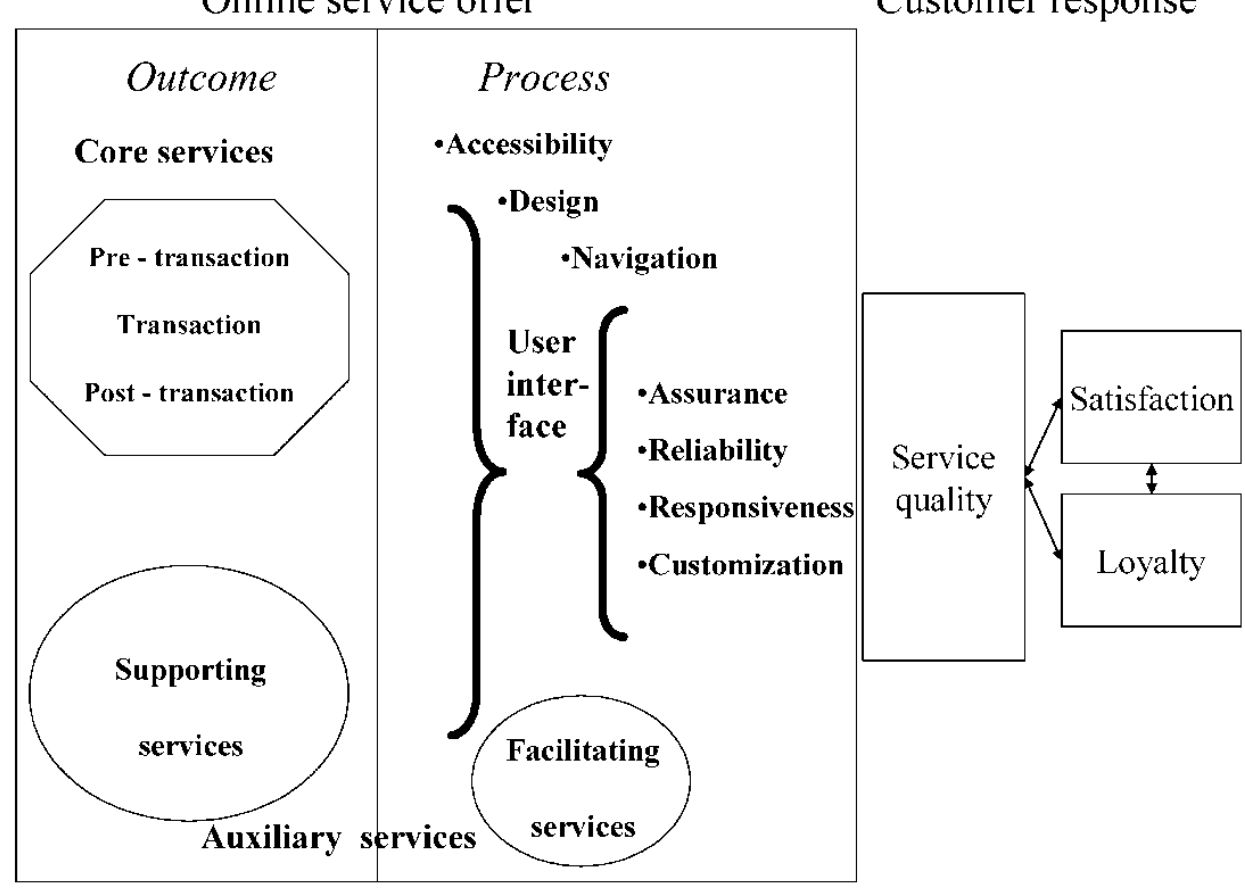

Figure 1. The role of the user interface in online services, adapted from Liljander et al. (2002)

of online services, the role of information technology (IT) is most clearly observable in the user interface (Grönroos et al., 2000). Therefore, an important quality dimension customers encounter when visiting a website is its functionality as an interface between themselves and the firm. Making a distinction between the process or technical, and outcome or functional aspects of service quality (Grönroos, 1994; Grönroos et al., 2000; Parasuraman et al., 1985; Parasuraman et al., 1991) the role of the user interface and the relationships between the various components the online service offer and customer responses can be visualized as depicted in Figure 1.

The technical functionality of the user interface determines how services are delivered to customers, and therefore affects functional quality perceptions of the core, facilitating and supporting services (Liljander et al., 2002) in pre-, postand transaction stages. Since the user interface replaces the physical service encounter, it substitutes the tangibles dimension of the SERVQUAL model (Kaynama \& Black, 2000; Szymanski \& Hise, 2000). How well the website succeeds as an interface between customer and provider will likely depend on two broad characteristics: the design of the pages as they appear on screen, and the ease with which customers can access and navigate between pages inside the website. The structure of travel websites is highly complicated, because they must allow the customer to retrieve and select detailed information chunks from many different databases and combine them into the desired information (Barnett \& 
Standing, 2001). The complexity and required amount of detail of the travel offer also make it difficult to display all required information efficiently and effectively. It is therefore expected, that the quality of the user interface will play a major role in the case of Internet travel agencies (Jeong et al., 2003). Propositions will now be formulated with respect to the role and importance of each of the dimensions for the case of online travel agencies. Zeithaml et al. (2000) suggest measuring user interface quality in three dimensions, namely accessibility, navigation and aesthetics. Based on the above reasoning we follow this approach in formulating three propositions relating to the user interface, which precede propositions with respect to the other four modified SERVQUAL dimensions.

\section{Accessibility}

High levels of interface quality would imply easy access to the site itself, to company staff, and to the different services when needed (Bell \& Tang, 1998; Cox \& Dale, 2001; Zeithaml et al., 2000). Therefore we propose:

$\mathrm{P}_{1}$ : In the case of Internet travel agencies, accessibility of the website, the services and staff will be positively related to overall quality perceptions.

\section{Navigation}

Good navigation quality entails that the site (1) provides functions helping customers to find what they need without difficulty, (2) offers user-friendly and high performance search engines, and (3) allows the customer to manoeuvre easily, logically and quickly back and forth through the pages (Jeong \& Lambert, 2001; Liljander et al., 2002; Zeithaml et al., 2000). Customers could be offered different ways of searching. For travel sites, high quality navigation would mean that the customers could easily perform complex searches on, for example, type of holiday, type of transportation, country, date and price. This appears crucial to online travel service quality. We therefore expect:

$\mathrm{P}_{2}$ : In the case of Internet travel agencies, perceived quality of navigation between pages will be positively related to overall quality perceptions.

Design

Website design quality is referred to as 'site aesthetics' by Zeithaml et al. (2000), or 'e-scape' (Van Riel et al., 2004; Viitanen et al., 2004). The way information is presented, in terms of colour use, layout, number, relevance and quality of pictures, font size and style, will affect the way customers respond to the service. The tangibles dimension of traditional SERVQUAL is strongly reflected in the design aspect of the user interface. It is thus expected that:

$\mathrm{P}_{3}$ : In the case of Internet travel agencies, perceived quality of the design of web pages and the presentation of information will be positively related to overall quality perceptions. 


\section{Reliability}

The next SERVQUAL dimension to be discussed and modified for online services is reliability. Parallel to the case of offline services, customers expect search engines, payment facilities etc to function reliably, and the information presented on the website to be dependable. Two aspects of online service reliability can be distinguished (Cox \& Dale, 2001). The process aspect of reliability perceptions is driven by the correct technical functioning of the site, or the technical aspects of the user interface, while the outcome aspect is defined by the accuracy of service promises, billing and product information (Zeithaml et al., 2000). For instance, online travel agencies are required to reserve and offer the correct number of seats in an aeroplane, offer the packages at the advertised prices, and reserve the correct type of hotel room for the number of nights requested by the customer. It can therefore be expected that:

$\mathrm{P}_{4}$ : In the case of Internet travel agencies, perceived reliability of the online services will be positively related to overall quality perceptions.

\section{Assurance}

In the classical SERVQUAL model an important quality dimension is assurance, or the degree to which service staff and premises instigate trust in the customer. Online customers generally cannot scrutinize the employees, or the physical facilities of the firm they are dealing with (Reichheld \& Schefter, 2000), so trust must be established in other ways. It is the impression of assurance the website makes on the customer that will lead to trust. The security and privacy dimension used by Zeithaml et al. (2000), which 'involves the degree to which the customer believes the site is safe from intrusion and personal information is protected' (Zeithaml et al., 2000: p. 16) is part of the assurance dimension. Trust is often claimed to be the most important online service quality dimension (Papadopoulou et al., 2001; Petersen, 2001; Roy et al., 2001; Urban et al., 2000). It is expected, that:

$\mathrm{P}_{5}$ : In the case of Internet travel agencies, perceived assurance of the online services will be positively related to overall quality perceptions.

\section{Responsiveness}

The quality of support customers receive when faced with questions or running into problems, and the speed with which this support is provided, largely determine customer evaluations of post transaction services. Customer support is also appreciated during the pre-transaction stage, particularly for online services: the online customer is relatively powerless in enforcing help, having to rely on the willingness of the firm to provide support. The faster and more accurately a provider responds to requests, the better the service will be evaluated. We therefore expect:

$\mathrm{P}_{6}$ : In the case of Internet travel agencies, a positive relationship will exist between perceived responsiveness and overall quality perceptions. 
Focus of the study

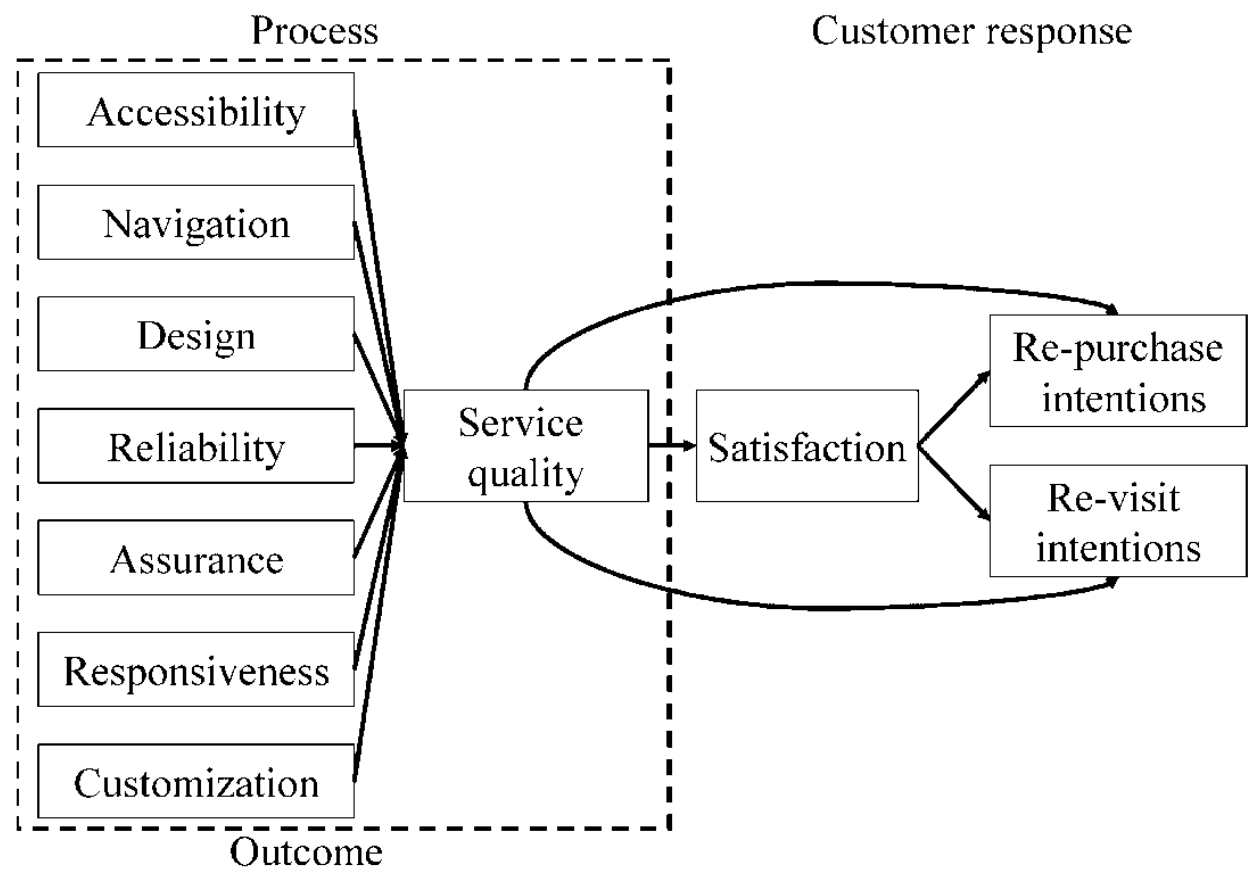

Figure 2. Research model

\section{Customization}

It has been argued that customizability is one of the key benefits of applying technology to the delivery process of services. Online services are, in principle, highly customizable. Customers may therefore expect online services to respond to their individual needs (Bitner et al., 2000). Customization is strongly related to the empathy dimension in SERVQUAL, as the online firm shows its appreciation of the customer's unique needs and preferences by making the site adaptable. However, companies often track customers' movements and decisions through interactions with the visited websites and use this database of client data for further customization (Kaynama \& Black, 2000). As a result, customization can easily involve privacy issues: To what extent customers will tolerate the prying behaviour of online providers remains to be seen. It can be expected, that:

$\mathrm{P}_{7}$ : In the case of Internet travel agencies, an inverted U-shaped relationship will exist between perceived customization and overall quality perceptions.

The expected relationships are summarized in the model in Figure 2.

\section{Research Design and Methodology}

A comparison of three existing travel sites in The Netherlands serves to validate the model by testing the propositions that were developed. After a short 
description of the travel industry in the Netherlands and of the three travel firms studied, the research methodology and the operationalization of the variables will be discussed.

\section{The Travel Industry in the Netherlands}

The Netherlands is a small country with 15 million inhabitants. It has one of the highest levels of personal computer and Internet penetration (Forrester, 2001) in households (after the US and Finland). The travel market can be divided into online, hybrid and traditional agencies. Furthermore, a distinction can be made between direct sellers and intermediaries. Direct sellers exclusively offer their own products. Examples are De Jong Intra (www.dejongintra.com), KrasSterVakanties (www.kras.nl), and ATPonline (www.atponline.nl). Direct sellers have direct insight in the availability of products, and can rapidly adapt the products to current demand. A disadvantage is the limited product offering on this type of site (Jungle Rating, 2001). For this reason, direct sellers tend to transform themselves into intermediaries (Barnett \& Standing, 2001). Intermediaries provide sites that sell products from a range of tour-operators. E-Bookers (www.ebookers.com), Elmar-reizen (www.elmar.nl), Travelplanet (www. travelplanet.nl), Happytravel (www.happytravel.nl), D-reizen (www.d-reizen.nl) and Travel24 (www.travel24.com) are examples of this category. Intermediaries tend to have the most attractive website design: 'When booking through an intermediary you really land in a virtual travel-world, where you can feel, compare and easily book, while sites of direct sellers are often without fantasy and atmosphere' (Jungle Rating, 2001).

\section{Three Travel Websites}

Three travel agencies, representing different categories, were used for this study: D-reizen (hybrid intermediary), Travel24 (online intermediary), and De Jong Intra (hybrid direct seller).

(1) D-reizen is the largest independent travel agency in the Netherlands. They sell bookings for nearly all Dutch tour operators (55 tour-operators, among others De Jong Intra) and airline companies.

(2) Travel24 is one of the most prominent travel agencies on the Internet. Travel24 is active in the Dutch-speaking Benelux-market, but also in Germany and other European countries and has agreements with many international touroperators. Most offerings can be booked online.

(3) De Jong Intra is a tour operator that caters to over 250,000 leisure travellers on a yearly basis. De Jong Intra sells their vacations via their website and through intermediaries (such as D-reizen).

\section{Questionnaire Design and Measurement}

A structured undisguised questionnaire was developed, containing 37 closed questions and five open questions. The questionnaire was sent by e-mail to a 
convenient sample of about 400 contacts on 7 May 2002, with the invitation to complete the questionnaire for at least one travel website. Links were provided to the three websites, and respondents were invited to visit and explore the sites before filling out the survey. Ninety-one respondents completed the questionnaire, 44 respondents for D-reizen, 20 respondents for De Jong Intra, and 27 respondents for Travel24.

In the original SERVQUAL model, service quality is defined as the difference between customers' expectations or anticipations and their perceptions of actual performance (Parasuraman et al., 1991). It has been suggested that service quality can be measured more appropriately as performance (Cronin \& Taylor, 1992, 1994). Service quality, measured as perceived performance, has been demonstrated to affect customer satisfaction and patronage behaviour directly and to a high degree (Cronin et al., 2000; Liljander \& Strandvik, 1995). It was therefore decided to measure service quality as respondents' self-reported agreement or disagreement with statements about the performance of the service on the previously discussed dimensions. Performance perceptions were measured on seven point Likert-scales.

\section{Results}

In a separate part of the survey, respondents were asked about the importance of various service categories offered by travel websites in general. Table 1 shows the means and standard deviations of the responses by age group.

Services directly related to transactions show an importance rating of at least 6 out of 7 in all categories and age groups. A notable difference between age groups was observed for responsiveness. Online customers in the 20-24 years old age group appear more impatient than the people in the other age groups. The various facilitating and supporting services show lower ratings, except for direct access, which reflects the desire to access the provider by phone or visit the premises if needed.

A factor analysis was used to assess the one-dimensional nature of the different variables. Cronbach's alpha was calculated for all constructs to obtain an

Table 1. Importance of online travel service categories by age group: Means (Std. dev.)

\begin{tabular}{|c|c|c|c|c|c|c|c|c|c|}
\hline \multirow[b]{2}{*}{ Age } & \multirow[b]{2}{*}{$N$} & \multicolumn{3}{|c|}{$\begin{array}{c}\text { Transaction related } \\
\text { services }\end{array}$} & \multicolumn{2}{|c|}{$\begin{array}{l}\text { Facilitating } \\
\text { services }\end{array}$} & \multicolumn{3}{|c|}{ Supporting services } \\
\hline & & $\begin{array}{l}\text { Fast } \\
\text { Response }\end{array}$ & Billing & $\begin{array}{l}\text { Confir- } \\
\text { mation }\end{array}$ & $\begin{array}{l}\text { Direct } \\
\text { access }\end{array}$ & E-mail & Country & Stories & $\begin{array}{l}\text { Chat } \\
\text { room }\end{array}$ \\
\hline Early 20 s & 39 & $\begin{array}{c}6.6 \\
(0.54)\end{array}$ & $\begin{array}{c}6.7 \\
(0.44)\end{array}$ & $\begin{array}{l}6.8 \\
(0.43)\end{array}$ & $\begin{array}{l}6.1 \\
(1.17)\end{array}$ & $\begin{array}{c}3.4 \\
(1.63)\end{array}$ & $\begin{array}{c}5.6 \\
(0.99)\end{array}$ & $\begin{array}{l}3.1 \\
(1.53)\end{array}$ & $\begin{array}{l}1.7 \\
(0.80)\end{array}$ \\
\hline Late 20 s & 23 & $\begin{array}{l}6.4 \\
(1.24)\end{array}$ & $\begin{array}{l}6.4 \\
(1.47)\end{array}$ & $\begin{array}{l}6.2 \\
(1.87)\end{array}$ & $\begin{array}{l}5.8 \\
(1.65)\end{array}$ & $\begin{array}{c}3.5 \\
(1.80)\end{array}$ & $\begin{array}{l}5.0 \\
(1.58)\end{array}$ & $\begin{array}{l}4.0 \\
(2.12)\end{array}$ & $\begin{array}{l}2.2 \\
(1.35)\end{array}$ \\
\hline 30s and above & 29 & $\begin{array}{c}6.0 \\
(0.98)\end{array}$ & $\begin{array}{c}6.6 \\
(0.88)\end{array}$ & $\begin{array}{l}6.7 \\
(0.81)\end{array}$ & $\begin{array}{c}5.4 \\
(1.52)\end{array}$ & $\begin{array}{l}4.0 \\
(1.66)\end{array}$ & $\begin{array}{c}5.28 \\
(1.28)\end{array}$ & $\begin{array}{l}3.6 \\
(1.40)\end{array}$ & $\begin{array}{l}2.4 \\
(1.48)\end{array}$ \\
\hline
\end{tabular}


indication of the composite reliability of the measures. Three separate factor analyses were conducted, one on the customer responses, one on the three user interface dimensions, and one on the other service quality dimensions. Scree tests were used to determine the number of factors. A value of 1 for the initial Eigenvalues was used as a threshold. Items measuring overall quality, satisfaction and behavioural intentions were loaded on one factor, explaining $65.2 \%$ of the total variance, with an initial Eigenvalue of 3.262. A three-factor solution was found for the user interface dimensions, explaining $74.6 \%$ of the total variance. Navigation (initial Eigenvalue 4.878) explained $49 \%$ of the variance, design (initial Eigenvalue 1.521) explained $15.2 \%$, and accessibility (initial Eigenvalue 1.043) explained 10.4\%. A three factor solution best described the remaining SERVQUAL dimensions, where customization (initial Eigenvalue 4.552) explained $50 \%$, assurance (initial Eigenvalue 1.197) explained 13.3\% and reliability (initial Eigenvalue 1.004) explained $11.15 \%$ of the total variance. Responsiveness was measured with a single item. Commonalities were all above 0.5 ; standardized factor loadings for most individual questions, relating to the user interface and the other service quality dimensions were high, whereas most of the factor analyses yielded acceptable values on the Kaiser-Meyer-Olkin measure of sampling adequacy (see Table 2), so these constructs can be considered reliable and one dimensional.

Means and standard deviations for service quality dimensions and overall rating of each site are reported in Table 3. For De Jong Intra, these values are consistently lower than for the other two sites (except site design).

To further explore the data, we calculated correlations between all main constructs. Table 4 presents bivariate correlations between core constructs. Correlation coefficients of respectively $0.10,0.30$ and 0.50 are typically interpreted as small, medium and large (Green et al., 1997).

Regression analysis was used to test the propositions. The expected relationships between the seven online service quality dimensions and customer responses are represented in the equation:

$$
\begin{aligned}
& S Q=\alpha+\beta 1 \times A C C+\beta 2 \times N A V+\beta 3 \times D E S+\beta 4 \times R E L+\beta 5 \times A S S+ \\
& \quad \beta 6 \times R E S+\beta 7 \times C U S+E
\end{aligned}
$$

where $\alpha$ is the intercept, $\beta 1-\beta 7$ are regression coefficients of the independent variables and $E$ represents the error term. Because of considerable correlations among the independent variables (see Table 4), high levels of multicollinearity were expected. The variance inflation factors (VIF) were calculated and found to be in the range of 1.5-3.5. In order to separate better the effects of the different independent variables a Ridge-regression was therefore conducted. In the case of multicollinearity, least squares estimates themselves are unbiased, but their variances are very large and possibly far from the true values. By adding a small bias $(k)$ to the regression estimates, more reliable estimates can be obtained. A value of 0.6 for $k$ was chosen, as this produced the best results. The regression results are reported in Table 5. From Table 5 it can be concluded that highly significant relationships exist between the two major user interface dimensions, navigation (Proposition 2) and design (Proposition 3), as well as the adapted 
Table 2. Factor analysis for the constructs

\begin{tabular}{|c|c|c|c|}
\hline $\begin{array}{l}\text { Construct/measures } \\
\text { (composite reliability/sampling adequacy) }\end{array}$ & $\begin{array}{l}\text { Standardized } \\
\text { loadings }\end{array}$ & Mean & $\begin{array}{l}\text { Std. } \\
\text { dev. }\end{array}$ \\
\hline \multicolumn{4}{|l|}{ Overall service quality $(\alpha=0.86 / \mathrm{KMO}=0.847)$} \\
\hline $\begin{array}{l}\text { The quality of services on the travel agency's website is very } \\
\text { good }\end{array}$ & 0.75 & 4.75 & 1.29 \\
\hline $\begin{array}{l}\text { On a scale between } 1 \text { (very bad) and } 7 \text { (very good) I would } \\
\text { grade the travel agency's website: }\end{array}$ & 0.80 & 4.78 & 1.25 \\
\hline I am very satisfied with the service on this website & 0.85 & 4.53 & 1.59 \\
\hline $\begin{array}{l}\text { In the future I will certainly make use of the website to } \\
\text { search for travel information }\end{array}$ & 0.86 & 4.41 & 1.78 \\
\hline $\begin{array}{l}\text { In the future I will certainly make use of the website to } \\
\text { book travel }\end{array}$ & 0.78 & 3.46 & 1.64 \\
\hline \multicolumn{4}{|l|}{ Accessibility $(\alpha=0.81 / \mathrm{KMO}=0.500)$} \\
\hline $\begin{array}{l}\text { The website makes it easy to get into touch with the travel } \\
\text { agency }\end{array}$ & 0.78 & 4.77 & 1.53 \\
\hline $\begin{array}{l}\text { I can easily find e-mail address and telephone number of } \\
\text { the travel agency }\end{array}$ & 0.92 & 4.69 & 1.79 \\
\hline \multicolumn{4}{|l|}{ Navigation $(\alpha=0.90 / \mathrm{KMO}=0.822)$} \\
\hline Browsing between pages is easy & 0.87 & 4.96 & 1.56 \\
\hline The structure of the site is logical & 0.91 & 4.89 & 1.62 \\
\hline A good search engine is present & 0.86 & 4.39 & 1.72 \\
\hline Categorization of topics is helpful in finding what I search & 0.88 & 4.81 & 1.63 \\
\hline \multicolumn{4}{|l|}{ Design $(\alpha=0.78 / \mathrm{KMO}=0.778)$} \\
\hline The site is pleasant to look at & 0.63 & 4.90 & 1.57 \\
\hline The site is original & 0.63 & 4.20 & 1.56 \\
\hline There are too many pictures (recoded) & 0.86 & 4.37 & 1.66 \\
\hline The use of colours on the site is good & 0.71 & 4.57 & 1.69 \\
\hline \multicolumn{4}{|l|}{ Reliability $(\alpha=0.81 / \mathrm{KMO}=0.852)$} \\
\hline The information provided by the travel agency is up-to date & 0.86 & 5.26 & 1.33 \\
\hline I can rely on the information provided on the website & 0.75 & 5.30 & 1.33 \\
\hline Product information (travel description) is accurate & 0.73 & 4.71 & 1.34 \\
\hline \multicolumn{4}{|l|}{ Assurance $(\alpha=0.80 / \mathrm{KMO}=0.700)$} \\
\hline The purpose of the site is entirely clear to me & 0.82 & 5.46 & 1.39 \\
\hline $\begin{array}{l}\text { I trust this site in terms of confidentiality of private } \\
\text { information }\end{array}$ & 0.84 & 4.85 & 1.38 \\
\hline $\begin{array}{l}\text { The website looks professional } \\
\text { Responsiveness }\end{array}$ & 0.87 & 5.08 & 1.51 \\
\hline Imagine having a problem, it is easy finding help on the site & 0.84 & 4.17 & 1.34 \\
\hline \multicolumn{4}{|l|}{ Customization $(\alpha=0.85 / \mathrm{KMO}=0.708)$} \\
\hline The site helps to find exactly what I want & 0.64 & 4.54 & 1.56 \\
\hline $\begin{array}{l}\text { The site is easy to customize (by offering the possibility to } \\
\text { search on date, destination and price) }\end{array}$ & 0.88 & 4.36 & 1.75 \\
\hline $\begin{array}{l}\text { I can quickly and easily see if they offer something that } \\
\text { suits me }\end{array}$ & 0.83 & 4.64 & 1.57 \\
\hline
\end{tabular}


Table 3. Descriptives for three travel websites: Means (Std. dev.)

\begin{tabular}{lccc}
\hline & De Jong Intra & Travel 24 & D-reizen \\
\hline Customer response (SQ) & $3.36(1.32)$ & $4.51(0.79)$ & $4.77(1.15)$ \\
Access (ACC) & $4.10(1.64)$ & $5.13(1.35)$ & $4.88(1.34)$ \\
Navigation (NAV) & $3.74(1.59)$ & $5.18(1.12)$ & $5.09(1.12)$ \\
Design (DES) & $4.31(1.48)$ & $4.26(0.68)$ & $4.87(1.23)$ \\
Reliability (REL) & $4.30(1.40)$ & $5.04(1.11)$ & $5.49(0.79)$ \\
Assurance (ASS) & $4.87(1.16)$ & $4.85(1.29)$ & $5.54(0.76)$ \\
Responsiveness (RES) & $3.95(1.47)$ & $4.11(1.31)$ & $4.40(1.16)$ \\
Customization (CUS) & $3.42(1.48)$ & $4.64(1.05)$ & $5.05(1.16)$ \\
\hline
\end{tabular}

Table 4. Correlation matrix of main constructs

\begin{tabular}{lccccccc}
\hline & SQ & ACC & NAV & DES & REL & ASS & RES \\
\hline ACC & $0.452^{* *}$ & & & & & & \\
NAV & $0.830^{* *}$ & $0.443^{* *}$ & & & & & \\
DES & $0.549^{* *}$ & $0.503^{* *}$ & $0.474^{* *}$ & & & & \\
REL & $0.553^{* *}$ & $0.232^{*}$ & $0.515^{* *}$ & $0.432^{* *}$ & & & \\
ASS & $0.533^{* *}$ & $0.470^{* *}$ & $0.576^{* *}$ & $0.678^{* *}$ & $0.554^{* *}$ & & \\
RES & $0.534^{* *}$ & $0.555^{* *}$ & $0.530^{* *}$ & $0.442^{* *}$ & $0.420^{* *}$ & $0.515^{* *}$ & \\
CUS & $0.806^{* *}$ & $0.388^{* *}$ & $0.818^{* *}$ & $0.448^{* *}$ & $0.496^{* *}$ & $0.525^{* *}$ & $0.570^{* *}$ \\
\hline
\end{tabular}

**Correlation is significant at the 0.01 level (2-tailed).

*Correlation is significant at the 0.05 level (2-tailed).

Table 5. Ridge regression $(k=0.6)$

\begin{tabular}{lccc}
\hline Dependent variable: SQ & B & $t$ & $\beta$ \\
\hline Intercept & 0.177 & $1.898^{*}$ & \\
NAV & & $8.578^{* *}$ & 0.272 \\
CUS & & $7.891^{* *}$ & 0.252 \\
REL & & $3.301^{* *}$ & 0.116 \\
DES & $3.302^{* *}$ & 0.113 \\
ACC & & $1.873^{*}$ & 0.065 \\
RES & & $1.784^{*}$ & 0.025 \\
ASS & & 0.752 & 0.025 \\
$N=91 \quad$ Adjusted $R^{2}: 0.71$ & & \\
F-value: 32.540 significance & & \\
$0.000^{* *}$ & & & \\
\hline
\end{tabular}

SERVQUAL dimensions reliability (Proposition 4) and customization (Proposition 7), and customer responses.

Weaker, but significant effects exist between accessibility (Proposition 1) and responsiveness (Proposition 6) and customer responses, while, surprisingly, no significant relationship could be found between assurance and customer responses (Proposition 5). A large proportion of the variance in customer responses was 
explained by the six significant constructs (adjusted $R^{2}=0.71$ ), while the model has a relatively good and highly significant fit to the data $(F=32.540)$. This implies that the data support all propositions, except Proposition 5.

\section{Discussion and Conclusions}

As a result of the rapid development of information and communication technologies, customers have gained access to a wide range of new services on the Internet (Porter, 2001). The present study focused on online travel services as one of the largest e-commerce domains (Anckar \& Walden, 2000; Clemons et al., 2002). The aim was to investigate the dimensions of online travel service quality by adapting and extending the SERVQUAL model. We investigated the impact of accessibility, navigation, design, reliability, responsiveness and customization on online service quality perceptions. Where traditional service quality perceptions are based on an evaluation of encounters between service provider and customers, online service quality perceptions appear to be generally based on evaluations of the interaction between the customer and a user interface. Each online service provider employs standardized interfaces and technology for its customers. Delivering online services right the first time every time is crucial. Imperfections in technology or user interface design have immediate consequences for online service quality perceptions in all dimensions. Furthermore, customers' zones of tolerance are likely to be smaller for online services, because a multitude of providers are available on the Web (Parasuraman et al., 1991; Van Riel et al., 2003).

The present study found that all factors, except assurance, had a significant impact. Our model explained $71 \%$ of the variance in perceived online service quality. As we found a weak antecedent role of assurance, the observation of substantial correlation between assurance and customer responses may point at reverse causality. This observation warrants further investigations. The impact of accessibility and responsiveness on online service quality perceptions was weaker, yet significant. The true importance of accessibility may be revealed to its full extent when the customers really need to contact the company, which may not have been the case in the sample used for the research. A similar observation can be made with respect to responsiveness. Customers expect companies to react quickly and accurately to questions, complaints and orders.

\section{Managerial Implications and Recommendations}

Some recommendations for managers of online travel services can be made. Providers often consider supporting and pre- and post-transaction online services non-essential and mainly use them to differentiate the service package. We argue that pre-and post-transaction service delivery, which is typically built around supporting services, may significantly impact overall quality perceptions. In the context of travel e-commerce, pre- as well as post-transaction services should arguably be considered potential core services, paving the way for future transactions.

The results of our study indicate that both process and outcome dimensions 
significantly impact service quality perceptions in an online travel context. It is often argued that customer expectations can more easily be exceeded in process than in outcome dimensions (Parasuraman et al., 1991). This is important in relation to online travel services, because the interaction between the customer and the website is a process dimension (user interface), and therefore online providers should ensure quality in this area at least as much as in their outcome dimensions (Cox \& Dale, 2001). The design of the user interface acts as a business card for the travel agency. User interface quality should be high, because it affects the overall image of the service provider. The navigation aspect of the user interface appears to be essential: Travel sites would gain much by extremely user-friendly navigation toolbars. Decisions to book a vacation through a travel website seem to depend on the presence of fast and reliable navigation tools and of an easy-to-use but functional search engine. Cumbersome navigation and search facilities, or processes that are constantly blocked by irrelevant pop-ups and banners, are likely to be detrimental to re-visiting and re-use of the website and thus to customer loyalty. The proper use of technology in all aspects of the user interface can be a significant asset of the service provider. Furthermore, technology can contribute to continuous improvement of the online service by studying patterns in the surfing behaviour of customers.

\section{Limitations and Suggestions for Further Research}

The distinction between pre-transaction, transaction and post-transaction service quality warrants further research. For instance, what is the relative effect of preand post-transaction service quality on the perceived overall service quality? The present study largely deals with pre-transaction service quality. Investigating the same customers during the transaction and post-transaction phases would yield new insights into the relative impact of pre-transaction service quality.

\section{Acknowledgements}

The authors gratefully acknowledge the contribution of Simone van Leeuwen, who executed the research as a part of the requirements for her Master's Thesis.

\section{References}

Adamic, L. A. \& Huberman, B. A. (2000) The nature of markets in the world wide web, Quarterly Journal of Electronic Commerce, 1(1), pp. 5-12.

Anckar, B. \& Walden, P. (2000) Destination Maui? An exploratory assessment of the efficacy of selfbooking in travel, Electronic Markets, 10(2), pp. 110-119.

Augustyn, M. M. (1998) The road to quality enhancement in tourism, International Journal of Contemporary Hospitality Management, 10(4), pp. 145-158.

Augustyn, M. M. \& Ho, S. K. (1998) Service quality and tourism, Journal of Travel Research, 37(1), pp. 71-76.

Babakus, E. \& Boller, G. W. (1992) An empirical assessment of the SERVQUAL scale, Journal of Business Research, 24(3), pp. 253-268.

Barnett, M. \& Standing, C. (2001) Repositioning travel agencies on the Internet, Journal of Vacation Marketing, 7(2), pp. 143-152. 
Bell, H. \& Tang, N. K. H. (1998) The effectiveness of commercial Internet web sites: a user's perspective, Internet Research: Electronic Networking Applications and Policy, 8(3), pp. 219-228.

Bitner, M. J. (1990) Evaluating service encounters: the effects of physical surroundings and employee responses, Journal of Marketing, 54(2), pp. 69-82.

Bitner, M. J. (1992) Servicescapes: the impact of physical surroundings on customers and employees, Journal of Marketing, 56(2), pp. 57-71.

Bitner, M. J., Booms, B. H. \& Stanfield Tetreault, M. (1990) The service encounter: diagnosing favorable and unfavorable incidents, Journal of Marketing, 54(1), pp. 71-84.

Bitner, M. J., Brown, S. W. \& Meuter, M. L. (2000) Technology infusion in service encounters, Journal of the Academy of Marketing Science, 28(1), pp. 138-149.

Bolton, R. N. \& Drew, J. H. (1992) Mitigating the effect of service encounters, Marketing Letters, 3(1), pp. $57-71$.

Bowen, D. \& Clarke, J. (2002) Reflections on tourist satisfaction research: past, present and future, Journal of Vacation Marketing, 8(4), pp. 297-308.

Brown, S. P., Ostrom, A. L. \& Brown, S. W. (2002) A meta-analysis of service quality relationships, levels, and structure. Working Paper (Tempe, AZ: Arizona State University).

Caruana, A., Ewing, A. E. \& Ramaseshan, M. (2000) Assessment of the three-column format SERVQUAL: an experimental approach, Journal of Business Research, 49, pp. 57-65.

Clemons, E. K., Hann, I.-H. \& Hitt, L. M. (2002) Price dispersion and differentiation in online travel: an empirical investigation, Management Science, 48(4), pp. 534-549.

Cox, J. \& Dale, B. G. (2001) Service quality and ecommerce: an exploratory analysis, Managing Service Quality, 11(2), pp. 121-131.

Cronin Jr., J. J. \& Taylor, S. A. (1992) Measuring service quality: a reexamination and extension, Journal of Marketing, 56(2), pp. 55-68.

Cronin Jr., J. J. \& Taylor, S. A. (1994) SERVPERF versus SERVQUAL: reconciling performance-based and perceptions-minus-expectations measurement of service quality, Journal of Marketing, 58(1), pp. $125-131$.

Cronin Jr., J. J., Brady, M. K. \& Hult, G. T. M. (2000) Assessing the effects of quality, value and customer satisfaction on consumer behavioral intentions in a service environment, Journal of Retailing, 76(2), pp. 193-218.

Dabholkar, P. A. (1996) Consumer evaluations of new technology-based self-service options: an investigation of alternative models, International Journal of Research in Marketing, 13(1), pp. 29-51.

Dabholkar, P. A. (2000) Technology in service delivery: implications for self-service and service support, in: T. A. Swartz \& D. Iacobucci (eds) Handbook of Services Marketing, pp. 103-110 (New York: Sage).

Dabholkar, P. A. \& Bagozzi, R. P. (2002) An attitudinal model of technology-based self-service: moderating effects of consumer traits and situational factors, Journal of the Academy of Marketing Science, 30(3), pp. 184-201.

Forrester Research (2001) NAPM/Forrester research report on E-business, Available at http://www.ism.ws/ismreport/forrester/frob102001.cfm (accessed 17 March 2002).

Green, S. B., Salkind, N. J. \& Akey, T. M. (1997) Using SPSS for Windows: Analyzing and Understanding Data (Upper Saddle River, NJ, Prentice Hall).

Grönroos, C. (1994) From marketing mix to relationship marketing, Management Decision, 32(2), pp. 4-17.

Grönroos, C., Heinonen, F., Isoniemi, K. \& Lindholm, M. (2000) The netoffer model: a case example from the virtual marketspace, Management Decision 38(4), pp. 243-252.

Groth, M., Gutek, M. G. \& Douma, A. (2001) Effects of service mechanisms and modes on customers' attributions about service delivery, Journal of Quality Management, 6(2), pp. 331-348.

Jeong, M. \& Lambert, C. (2001) Adaptation of an information quality framework to measure customers' behavioral intentions to use lodging web sites, International Journal of Hospitality Management, 20(2), pp. 129-146.

Jeong, M., Oh, M. \& Gregoire, O. (2003) Conceptualizing web site quality and its consequences in the lodging industry, International Journal of Hospitality Management, 22(2), pp. 161-175.

Jungle Rating (2001) Nieuwe intermediairs overtroeven traditionele reisorganisaties op Internet (New intermediaries outdo traditional travel agencies on the Internet), Available at http://www.junglerating.nl/nieuws/029.asp (accessed 13 April 2002).

Kaynama, S. A. \& Black, C. I. (2000) A proposal to assess the service quality of online travel agencies: an exploratory study, Journal of Professional Services Marketing, 21(1), pp. 63-88. 
Liljander, V. \& Strandvik, T. (1995) The relation between service quality, satisfaction and intentions, in: P. Kunst \& J. Lemmink (eds) Managing Service Quality, pp. 45-63 (London: Paul Chapman Publishing).

Liljander, V., Van Riel, A. C. R. \& Pura, M. (2002) Customer satisfaction with e-services: The case of an on-line recruitment portal, in: M. Bruhn \& B. Stauss (eds) Jahrbuch Dienstleistungsmanagement 2002-Electronic Services, pp. 407-432 (Wiesbaden: Gabler).

Meuter, M. L. \& Bitner, M. J. (1998) Self-service technologies: extending service frameworks and identifying issues for research, American Marketing Association (Winter), pp. 12-19.

Meuter, M. L., Ostrom, A. L., Roundtree, R. I. \& Bitner, M. J. (2000) Self-service technologies: understanding customer satisfaction with technology-based service encounters, Journal of Marketing 64(3), pp. 50-64.

Meuter, M. L., Bitner, M. J. \& Ostrom, A. L. (2001) Consumer adoption of self-service technologies: model development and assessment, in: R. T. Rust Proceedings of Frontiers in Services (Washington DC).

Morgan, N. J., Pritchard, A. \& Abbott, S. (2001) Consumers, travel and technology: a bright future for the web or television shopping? Journal of Vacation Marketing, 7(2), pp. 110-124.

Oliver, R. L. (1977) The effects of expectations and disconfirmation on post-exposure product evaluations, Journal of Applied Psychology, 62(2), pp. 246-250.

Oliver, R. L. (1999) Whence customer loyalty? Journal of Marketing, 63(4, pp. 33-44.

Pan, X., Ratchford, X. R. \& Shankar, B. (2002) Can price dispersion in online markets be explained by differences in e-tailer service quality? Journal of the Academy of Marketing Science, 30(4, pp. 433-445.

Papadopoulou, P., Andreou, A., Kanellis, P. \& Martakos, D. (2001) Trust and relationship building in electronic commerce, Internet Research: Electronic Networking and Policy 11(4), pp. 322-332.

Parasuraman, A. \& Grewal, D. (2000) The impact of technology on the quality-value-loyalty chain: a research agenda, Journal of the Academy of Marketing Science, 28(1), pp. 168-174.

Parasuraman, A., Berry, L. L. \& Zeithaml, V. A. (1985) A conceptual model of service quality and its implications for future research, Journal of Marketing, 49(4), pp. 41-50.

Parasuraman, A., Zeithaml, V. A. \& Berry, L. L. (1988) Servqual: A multiple item scale for measuring consumer perceptions of service quality, Journal of Retailing, 64(1), pp. 12-40.

Parasuraman, A., Berry, L. L. \& Zeithaml, V. A. (1991) Understanding customer expectations of service, Sloan Management Review, 32(3), pp. 39-48.

Petersen, A. (2001) Private matters: it seems that trust equals revenue, even online, The Wall Street Journal Europe, Special Section on E-Commerce (February 12), p. viii.

Peterson, R. A., Balasubramanian, S. \& Bronnenberg, B. J. (1997) Exploring the implications of the Internet for consumer marketing, Journal of the Academy of Marketing Science, 25(4), pp. 329-346.

Porter, M. E. (2001) Strategy and the Internet, Harvard Business Review, 79(3), pp. 63-78.

Reibstein, D. J. (2002) What attracts customers to online stores, and what keeps them coming back? Journal of the Academy of Marketing Science, 30(4), pp. 465-473.

Reichheld, F. F. (1994) Loyalty and the renaissance of marketing, Marketing Management, 2(4), pp. 10-22.

Reichheld, F. F. \& Schefter, P. (2000) E-loyalty: your secret weapon on the web, Harvard Business Review, 78(4), pp. $105-113$.

Reichheld, F. F. \& Teal, T. (1996) The Loyalty Effect: The Hidden Force behind Growth, Profits and Lasting Value (Boston, MA: Harvard Business School Press).

Reichheld, F. F., Markey Jr., R. G. \& Hopton, C. (2000) E-customer loyalty-applying the traditional rules of business for online success, European Business Journal, 12(4), pp. 173-179.

Roy, M. C., Dewit, O. \& Aubert, B. A. (2001) The impact of interface usability on trust in web retailers, Internet Research: Electronic Networking Applications and Policy, 11(5), pp. 388-398.

Rust, R. T. \& Oliver, R. L. (2000) Should we delight the customer, Journal of the Academy of Marketing Science, 28(1), pp. 86-94.

Shankar, V., Smith, V. S. \& Rangaswamy, A. (2003) Customer satisfaction and loyalty in online and offline environments, International Journal of Research in Marketing, 20(2), pp. 153-175.

Smith, M. D. (2002) The impact of shopbots on electronic markets, Journal of the Academy of Marketing Science, 30(4), pp. 446-454.

Solomon, M. R., Surprenant, C., Czepiel, J. A. \& Gutman, E. G. (1985) A role theory perspective on dyadic interactions: the service encounter, Journal of Marketing 49(1), pp. 99-111.

Szymanski, D. M. \& Hise, R. T. (2000) E-satisfaction: An initial examination, Journal of Retailing, 76(3), pp. $309-322$. 
TravelWeekly (2001) Online travel trends, Travel Weekly, 24 September, pp. 1-4.

Urban, G. L., Sultan, F. \& Qualls, W. J. (2000) Placing trust at the center of your Internet strategy, Sloan Management Review, 42(1), pp. 39-48.

Van Riel, A. C. R., Semeijn, J. \& Janssen, W. (2003) E-service quality expectations: a case study, Total Quality Management \& Business Excellence 14(4), pp. 437-450.

Van Riel, A. C. R., Lemmink, J., Streukens, S. \& Liljander, V. (2004) Boost customer loyalty with online support: the case of mobile telecoms providers, International Journal of Internet Marketing and Advertising 1(1), pp. 4-23.

Viitanen, J., Liljander, V., Pura, M. \& Van Riel, A. C. R. (2004) Customer loyalty to content-based web sites: the case of an online health care service, Journal of Services Marketing, 18, Forthcoming.

Wind, J. \& Rangaswamy, A. (2001) Customerization: the next revolution in mass customization, Journal of Interactive Marketing, 15(1), pp. 13-32.

Zeithaml, V. A. \& Bitner, M. J. (2000) Services Marketing: Integrating Customer Focus across the Firm, 2nd edn (Boston, MA: McGraw-Hill).

Zeithaml, V. A., Berry, L. L. \& Parasuraman, A. (1996) The behavioral consequences of service quality, Journal of Marketing, 60(2), pp. 31-46.

Zeithaml, V. A., Parasuraman, A. \& Malhotra, A. (2000) A conceptual framework for understanding e-service quality: Implications for future research and managerial practice. Working Paper, Report Nr. 00-115 (Cambridge, MA: Marketing Science Institute).

Zeithaml, V. A., Parasuraman, A. \& Malhotra, A. (2002) Service quality delivery through web sites: A critical review of extant knowledge, Journal of the Academy of Marketing Science, 30(4), pp. 362-375. 